\title{
The Role of Local Calcium Deposit for the Healing Process of Fractures on Rachitic Rabbits
}

\author{
By \\ Kinya Hisamoto
}

Department of Orthopedic Surgery, Kokura Labour Accidental Hospital

Union did not occured, when the $1 / 3$ of radius on rachitic rabbits together with periostium had been excised.

Triple calcium phrsphate and calcium carbonate, boiled bone powder, boiled bone cip und autogenous bone chip, as the bone elements, were inserted in its gaps. The rabbits that rachitic changes were slight or middle taked union, though the healing of fractures were some delayed, but the rabbits indicated the changes of high degree scheu union after $9 \sim 10$ weeks occationally.

As entcalcificated bone cip was inserted in its gaps, union was not indicated.

The rate of speed on the healing of fractures in the rickets was not influenced by kinds of bone elements and indicated union in propotion to intensification of rachitic changes.

\section{柳澤氏血清 $\mathrm{Ca}$ 及同イオン定量法の検討}

九州大學蹬學部整形外科學教空 (主任 天罗敎授) 花 : 北良臣

演題は透析性 $\mathrm{Ca}$ となつているが，之を論晾には当然総Ca が問題とをるので先づ之に就て述べ たんと思う。

血清Ca の定量については今迄に幾多の方法が発表され，1947年夏，「アメリカ」疫痢調查団が来 朝した祭のCa定量法に関して b吉川氏が Sobel法の変法ではするが其の方法を詳しく述べている

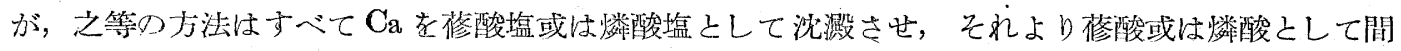

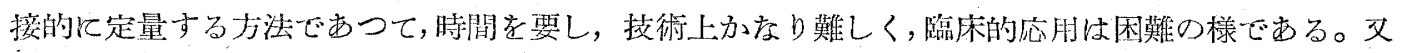
最近石井氏は Ethylendiamine tetraacetic acid の錯塩がCa及びMgイオン上特異的に結合するのを 利用する Schwarzenbach 法を追試し, Sobelkよる值之殆ど変らないと発表し推溪しているが私忙 Sunchromin Fast Blūeを用い比色により测定する新微量法を追試し知見を得てので報告する。 此の柳沢氏法の抄録は「整形外科と災害外科」第一巻第一号来尾紹介してあるが其の方法の概胳 ルつレて述ベると, Sunchromin Fast Blue はクロール，フェノール，アゾデオキシナフタリン， 
ヂスルフオン酸ナトリウムの事で赤色粉末状を呈し，白紙にすりつけると紫色の条痕を残し，苛性 ソーダを加えると紫色飞変色するが， $\mathrm{Ca}, \mathrm{Be}$ の存在で赤色を示す。Be は血清中に其の存在孝認め ないので，此の性質がCaの定量飞応䏳出来るわけである。

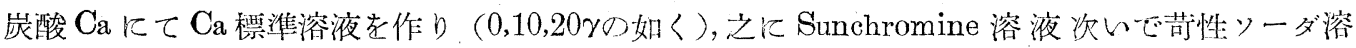

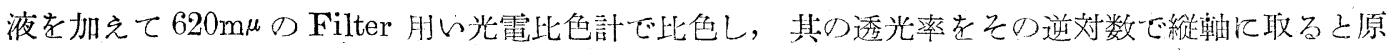
点を通る綺麗な直線を以て $\mathrm{Ca}$ 含有量と透光率之の関係が得られる。之を基準腘線として用いい る。

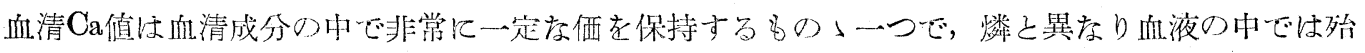
んど血清てのみ存在し，主として上皮小体ホルモンにより調節されるのみで変化の少い成分と云わ

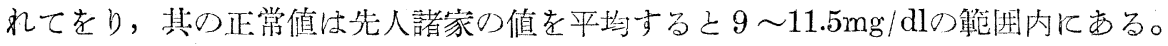

私は柳沢氏法により健康人 30 例の Ca 值を测定しを結果を得を。その平均值は $10.3 \mathrm{mg} / \mathrm{dl}$ となり 先人諸芜の正常值と比較するとスライド 3 の如くなり，正常範囲内てあるととを知つた。又惻沢氏

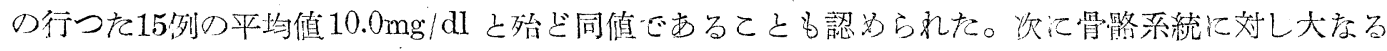

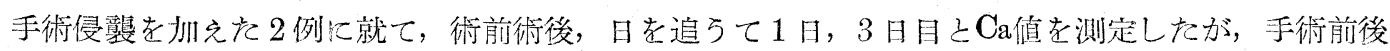
で殆んど有意の差を認めなかつた。又此の河野(今)例汇ついて血清採取後の時間, 温度との関係を 吟味するたか，採取せる日亿测定した後，窒温飞放琶し，24特間後再び测定を試みたが，其の测定 值の間にも大した変化はなく, Ca值は粼及フォスフナターゼと異り測定迄の時間, 温度に大して左 右せられないるのである事を知つた。

次に演題に揭げを所謂透析性Ca即ち広義のCaイオンに就いてであるが, 血清中Ca分屑の中理化学 的作用に主として与るのは，此のイオン化せるCaであると云われているのー゙其の変化の意義は重要 と考えられる。血清Caつ分㻺に就て種くの説が述べられているがMcLean等によると総Caの中5 mg

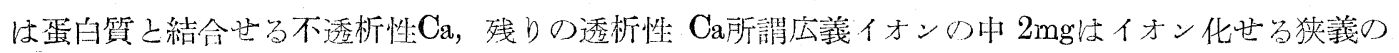
Caイオンで残り $3 \mathrm{mg}$ はイオン化していないと云つている。

此の透析性Carついても McLeanの理論的方法, Toksoyの透析膜法等が挙げられていながら䁒床 的応用は困難であつたが，最近柳沢氏が修酸安門老䏳いて総 $\mathrm{Ca}$ と同様に定量する方法を発表してい るので追試を行つた。

20例の健康人の柳沢氏法による测定值によれば其の值が個人により，又修酸安門を加えてから

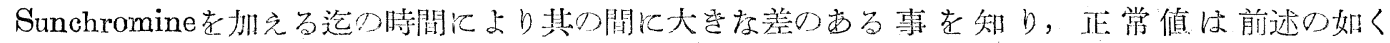

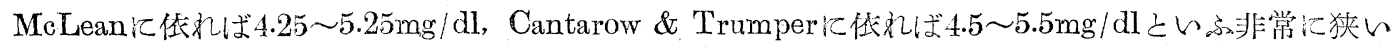
範畔にある事から，柳沢氏法そのものと疑問を抱を基礎的実験を試みた。即ら此の测定法の原理 は，4\%即ち飽和修酸安門を血清に加えてから時間の経過てつれてCaが修酸として沈澱するので柳 沢氏は此の沈澱と時閒との関係孝一つの曲線として得た。即ちA点（2 分後）で階段状に Caの沈 澱が緩慢になり其の後約 $3 \sim 5$ 分は殆んど一定值を保つているので柳沢氏は此の階段が透析性 Ca 


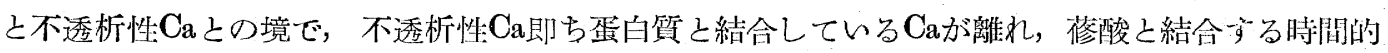

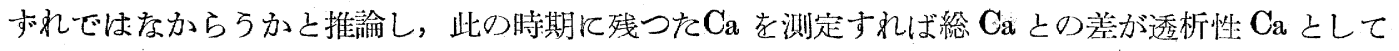
得られるといつている。

然るに私の 4 例に就ての同様実験の平均值からは図 8 (省略) 点線の如を曲線となり, 急激に下降 し，修酸アンモンを加えて $1 \sim 3$ 分後には既にCa忪て沈澱してしまうという急降下の曲線が得ら れた。依て原法通り $1 \sim 3$ 分後に, 葆酸安門を加えた血清にSūnchromineを添加した場合, 寸べて が透析性 Ca之なる矛盾を認め, 前述20 例の测定には修婹安門を加えた直後にSunchromineを加えて 定量したので，理論的汇は透析性Caの值ではない訳で，只此の短時閒に菱酸安門に上り沈澱したCa

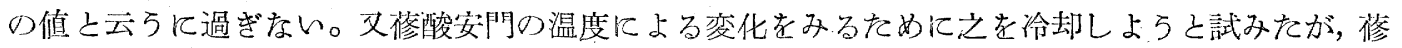
酸安門は $4 \%$ で飽和であり， $15^{\circ} \mathrm{C} て ゙$ 最も水に溶解し $15^{\circ} \mathrm{C}$ 以下になると過飽和となり，無色斜方晶形 の結晶老析出するので正確な $4 \%$ 濃度は得られず，温度は $15^{\circ} \mathrm{C}$ 亿保持する妥当之考える。

更に柳沢氏の此の曲線が正確であるとしても, 修酸安門老加えてからSünchromin を加える迄の

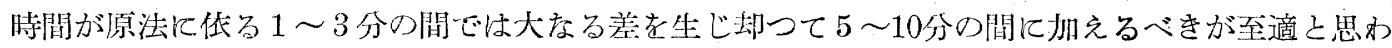
礼る。

今後更に撖密な追試検討 0 必要は大いて認めるとしても $4.25 \sim 5.25 \mathrm{mg} / \mathrm{dl}$ といふ極めて狭い正常 範国の透析性Caを斯の如き推論飞基づくオ法によつて定量する事は大なる誤差を生ずる恐れがあ り，却つて血清蛋白質量と総Ca量より計算によつて求めるMcLeanの方法が其の测定さへ正しく行 われる素らば，信朋価するのではないかと考える。

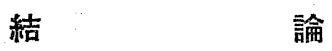

私は仰沢氏法により，主に健康人の血清中総Ca及透析性Caの定量を行い，次のやらな結果孝得 た。

先づ総 $\mathrm{Ca}$ の定量に就ては, 更に他の定量法と比較検討の必要はあるが, 私の経験として二, 三の実 験も行い，次の如き测定時の注意を厳守寸るならば. 総Ca定量て関する限り簡便に栾床上信頼して 利用する価值ありと信ずる。

即ち 1）Sunchromine稀釈液を正確に調製し褪色するので常に褐色瓶に保存し，楖沢氏の処方で 光電比色計のふれが少い時は 2 倍に濃くする事，又苛性ソーダをひんぱんに作りかえる事。

2）新しく調製した試薬に上り测定を行らとをは，必基準訮線を更新しなければ必和多少の変 化がある。出来得ればSunchromineつ褪色, 苛性ソーダ溶液の吸湿によるpHの変化を予想して基準 曲線は测定の都度更新するのが望ましい。

3）其の他一般的な光電比色計の使用法飞習熟与る事。

而して此の方法により健康人30例の平均值は $10.3 \mathrm{mg} / \mathrm{dl}$ となり文しい例ながら，骨骼芽統に大

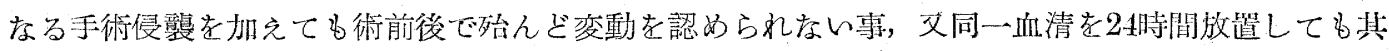
の测定值为略々一定である事起知つた。更に今後病的症例について，其の変化孝検討したい之思 万。 
次に透析性Caについては, 私の前述せる20例の测定值は結果より見れば理論的には透析性Ca值で はない事，二三の基礎的実験及文献的考察から考えると原法て疑間があり簡便で壮あるが，現在の 処隍床的応用は佾早の感がある。

演題の最後に示したShinowara法によるアルカリ性フォスフアターゼに関して，データ之一応の 結論は得ているが，Caとは及別のものであり，時間の関係上本日は省略し次の機会に譲りたいと思 5。

\title{
交譬
}

1) Krammer d.Tisdall : Journ. of Biol. Chem., 48:223, $1921 . \quad$ 2) Clark d. Collip : J. Biol. Chem., 63:461, 1925. 3) Sobel d.Skersky : J.Biol.Chem., 122:665,1938. 4) 吉川 : 血清中カル

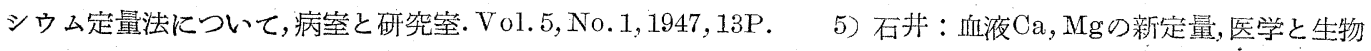
学, Vol.24 No.1.27,9P 6) 柳沢：血清Ca更血清Caイオンの新微量法, 綜合医学 Vol.8,No.12. 7) Abraham Cantarow : Diseases of Metabolism: Duncun.2nd Edition.1947. 8) Cantarow \& Trumper: Clinical Biochemiotry, 2nd Edition, 1939. 9) Franklin C, MeLean \& Hastings, Am. J. of the Medical Seiences. Vol 189, No.5.1935,P601. 10) 天罗: 骨疾患の血液化学的診断について. 「整形外科」Vol.1.No.1.昭25年 1月，12) Lederle Bulletin.Vol 15, No.4. Novemb.1950.

\section{Examinations on the Determination of Calcium Concentration}

\section{in the Blood by Yanagizawa's Method.}

\author{
By
}

\section{By Yoshimi Hanakita}

\author{
Department of Orthopedic Surgery, Faculty of Medicine, Kyushü University \\ (Prof.Amako)
}

Recently, I have studied on calcium determination by Yanagizawas' method. It makes use of property that Sunchromin Fast Blue M.B produces a special colour (violet) in existence of calcium in the alkaline solution.

(1) Total calcium concentration: It must be taked more examinations to compare with other methods (to determine the total calcium concentration in serum), but $I$ have believed that it is fairly reliable method for clinical determination. In 30 cases of the normal adult, the average of the total calcium concentration in serum was $10.3 \mathrm{mg} / \mathrm{dl}$.

(2) diffusible calcium concentration: I could not get a satisfactory result from this method about the determination of diffusible calcium concentration. It is believed that the clinical worth is doubtful in present day. 